\title{
التلازم بين الخوف والقلق ألم إنسانية الإنسان
}

أ.م.د هسبن همود الطائي

كلبة الآداب - الجامعة المستنـصرية

|

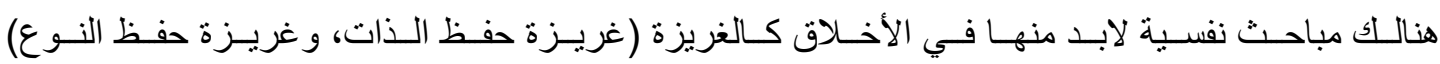

وكذللك غريزة الخوف بالإضافة إلى القلق.

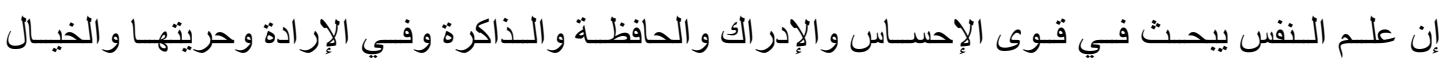

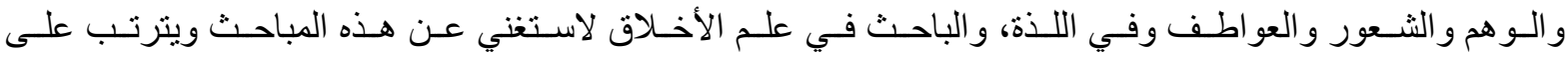

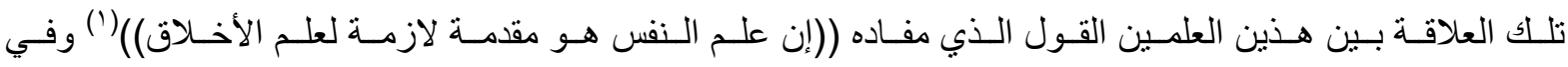

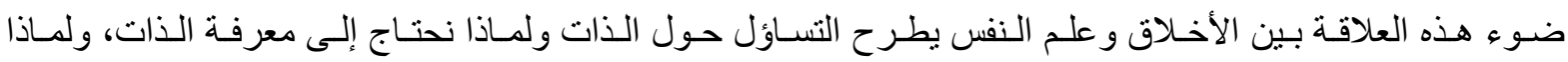

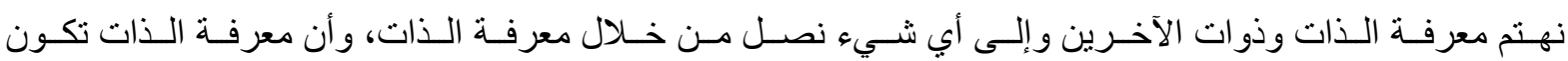
مقدمة لأي شيء.

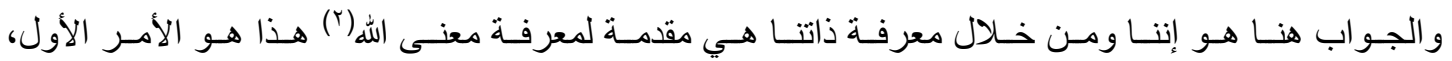

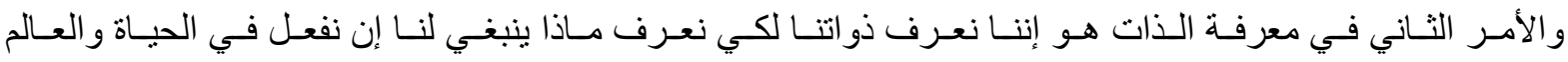

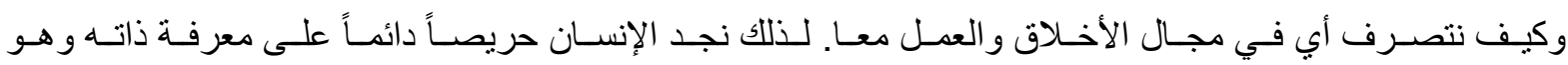
يخشى ذاتـه وربمـا يخثى الآخـرين خوفـا على هـذه الـذات مـن إن لاتصـل إلىى الدرجـة التـي تشـعر ها بإنسـانيتها

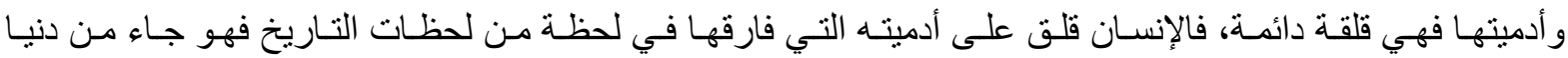

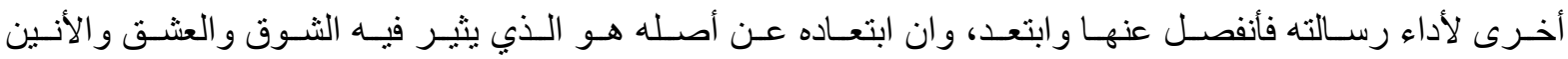

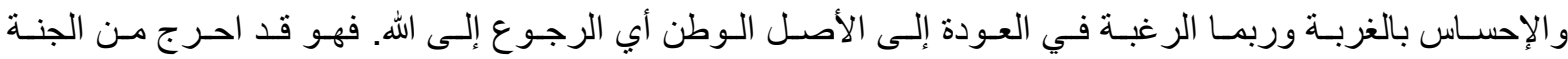

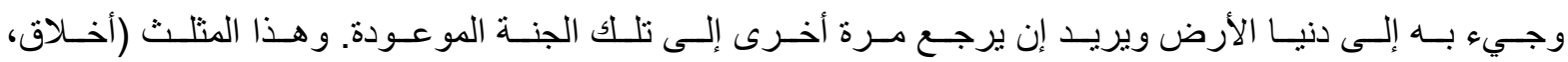

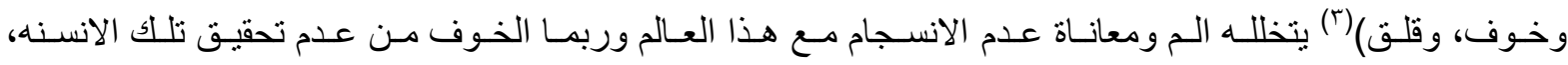
وكم هو عدد الذين عاثـوا وغـادروا هذه الحياة ولم يصلو ا إلى هذه المرحلـة بل لم يتألموا حتى لإنسـانيتهم لأنهم

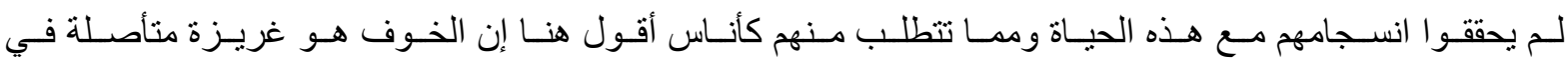

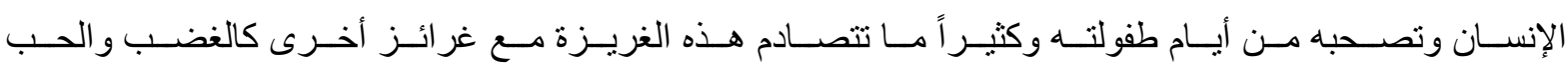

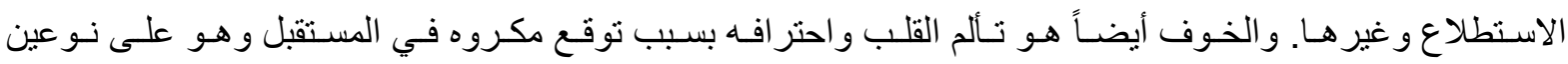

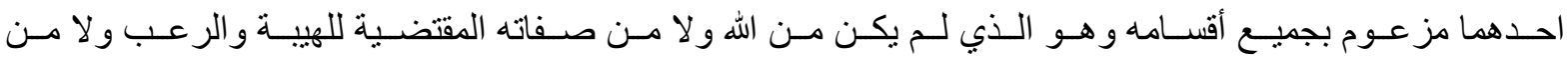

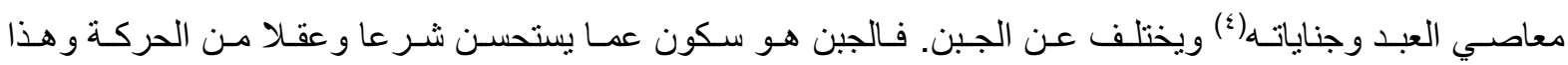

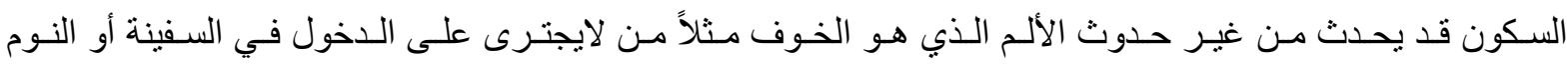

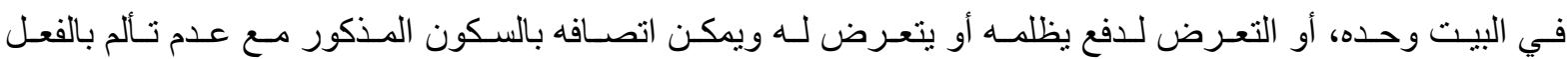
فمثله جبان ويس بخائف(ْ).

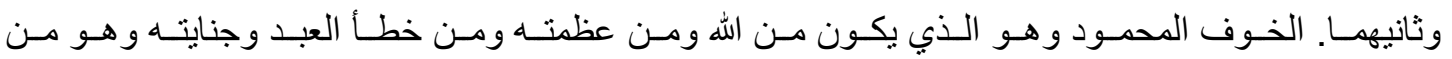

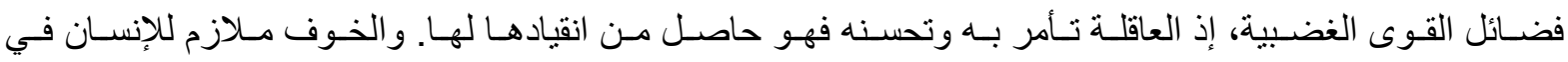

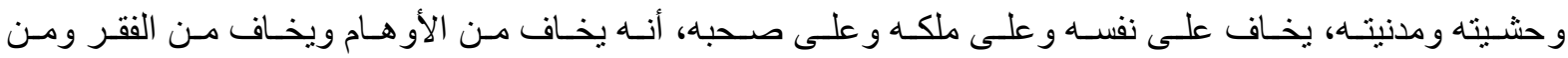


كبر السـن ومـن المـوت فهو عبد للخوف حتى يمـوت(؟) إمـا عن القلق فهو خوف غير محدد وغير عقلانسي وهو

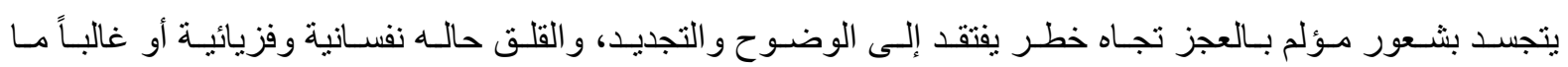

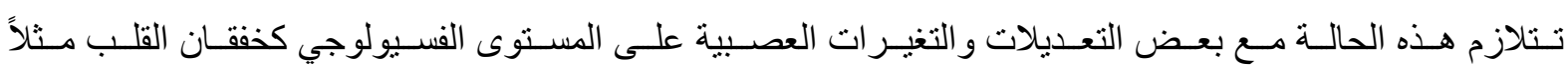
و الارتجاف كذلك.

ومـن وجهـة نظـر نكوينيـة يــرز القلق للمـرة الأولى حين ييلـغ الطفل الثـهر الثـامن وذلك في غيـاب إلام

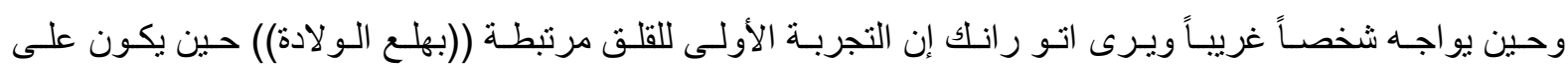

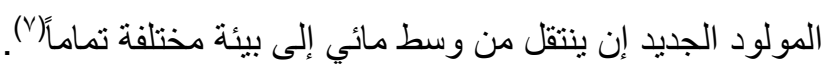
و القلق حالـة تتسـم بتوقع الخطـر أو بـالتهيؤ لـه وهو يختلف عن الذعر، فالذعر يمثل حالـة يولدها خطـر

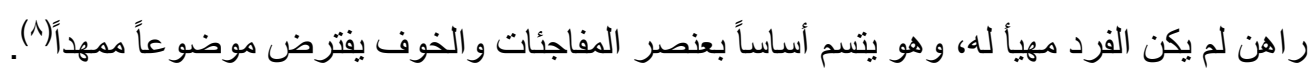

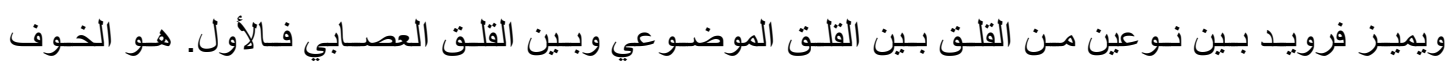

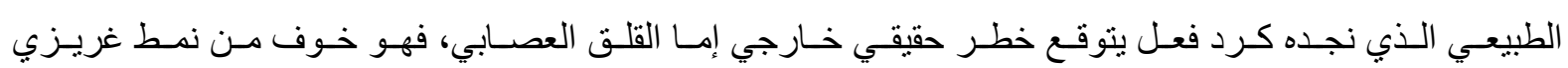

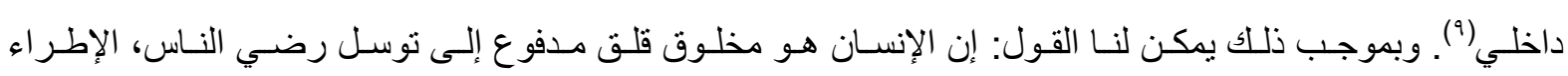

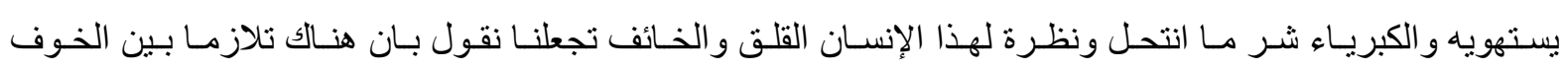

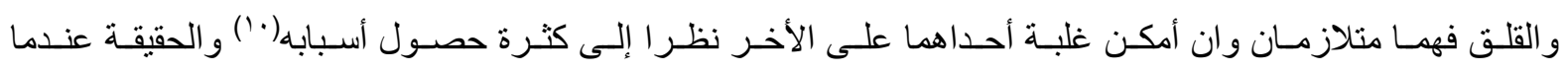

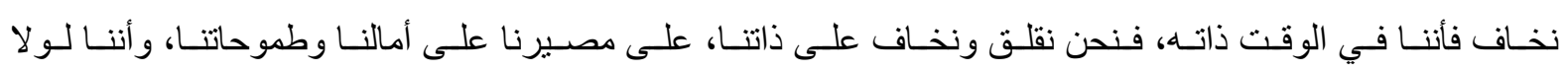
الخوف و القلق لما تمكنا من تحسين أفعالنا وتقويم سلوكياتنا فهما محمودان أحياناً ومذمومان في أحيانا أخر .

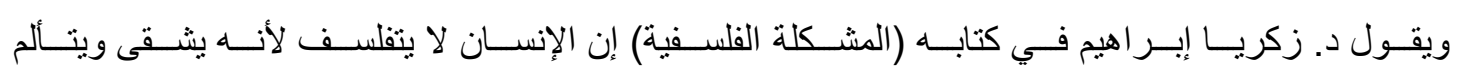

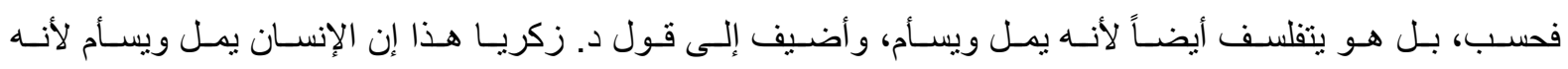

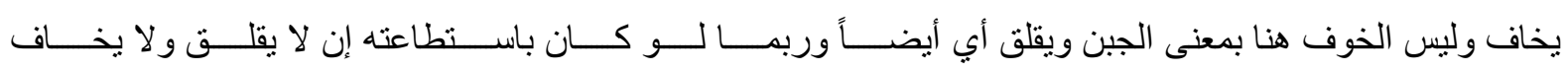

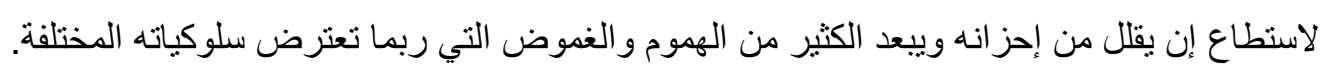

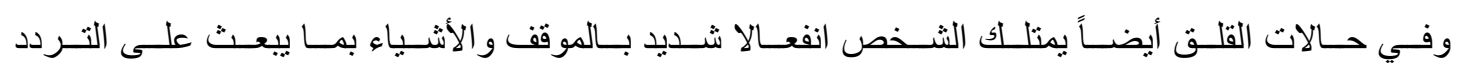

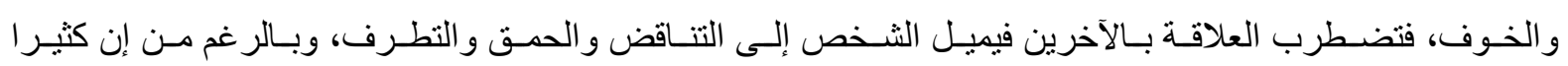

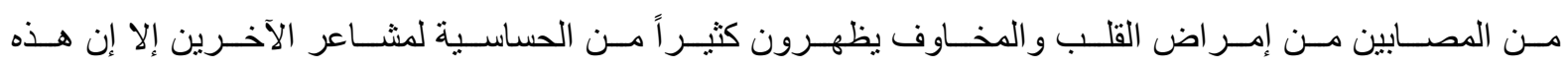

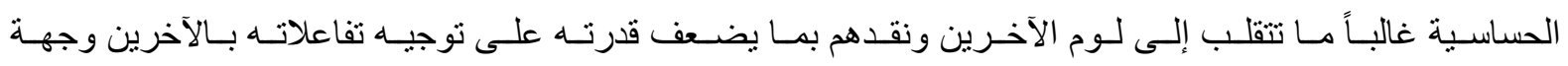

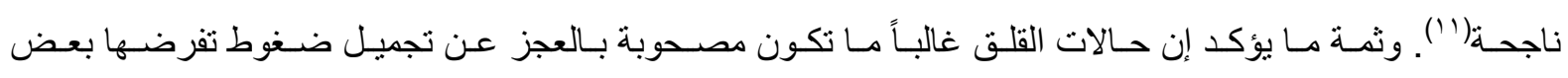

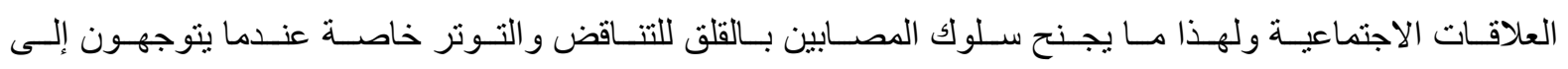
أساليب أخرى للتخفيف من القلق(r')

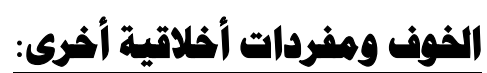

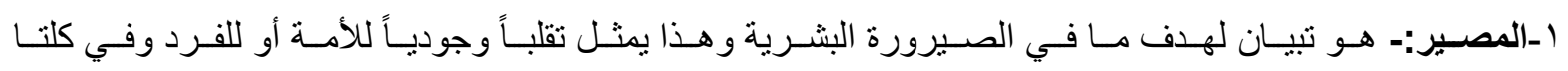
الحالتين ينطوي مفهوم المصير على معنى يريد العقل أو يبرد الوجود التناريخي.

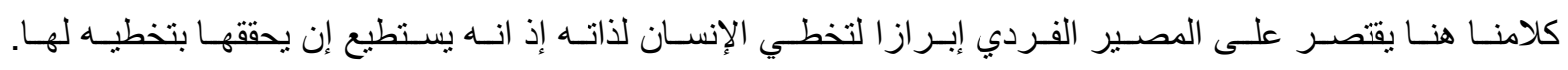

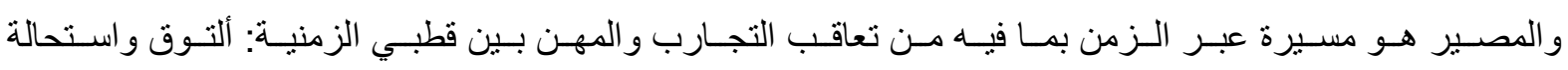


النكـوص. فالحيـاة كمــا تبـدو للإنسـان لـيس بـالأمر المهم بـل هـي في الو اقـع لا شـيء مـن حيـث المعنس. هـي لا تمنحه الشعور بالكمال إلا في هنيهات نادرة مشعة بالحنين.

ذللك إن الطـابع المميـز للمصـير البشـري هـو النقصـان، فالإنسـان لا ينف الك يعتريـه شـور بـنقص مـا هـو ضـروري

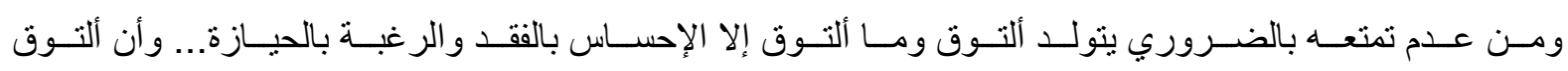

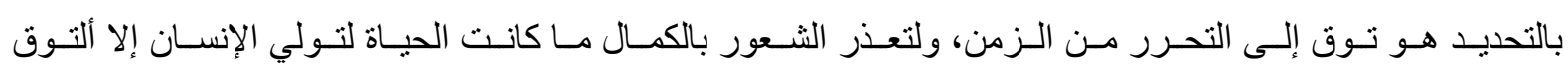

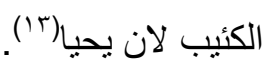

( (1)-فالوجـه الأول للمصـير البشـري وجـه حيـواني و هنـا لا تعمل البصـيرة البشـرية في تيـار معـاكس بـل في تيـار نشاطها المتعلق بالتناسل والاختر اق.

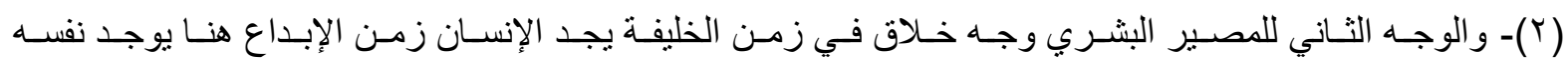
بنفسه زمنه المكتف الذي يظهر من خلال العمل. و المعنى الأسمى لفعل الإبداع هو إفراز غير المحدود في الزمن المحدود.

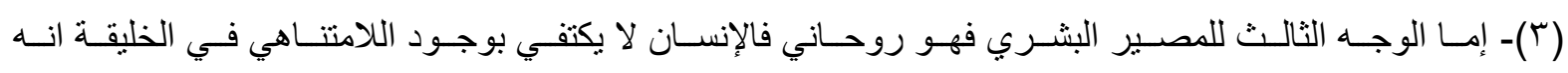

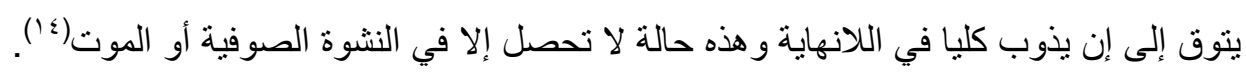

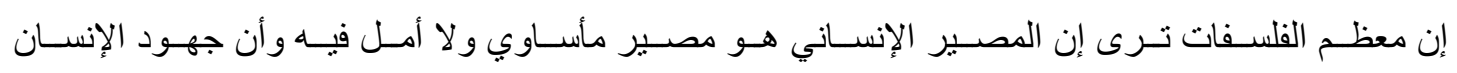

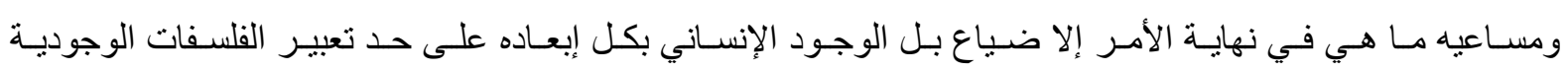

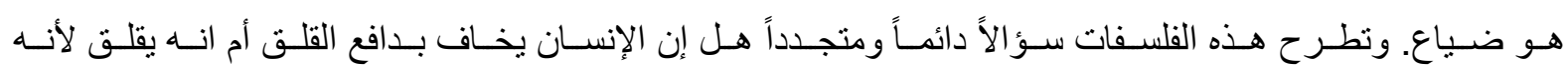

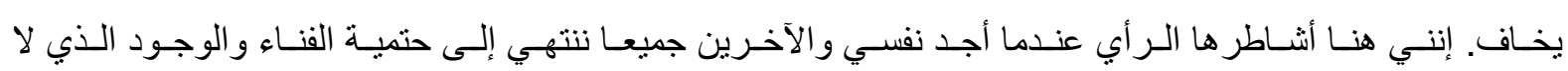
مفر منه.

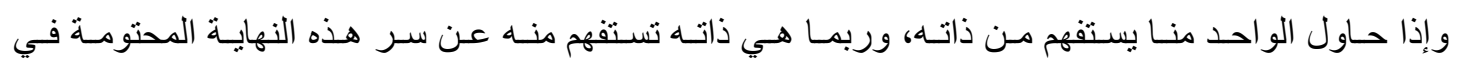

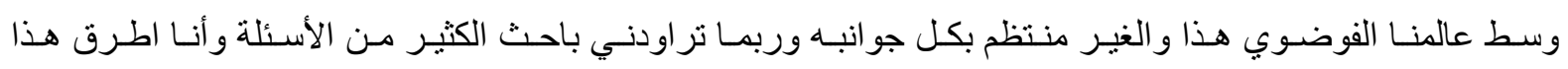

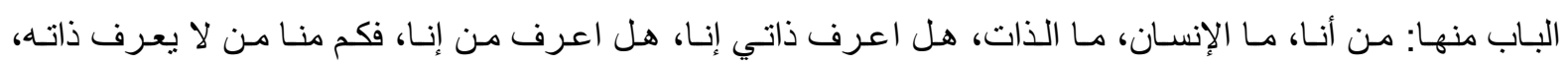

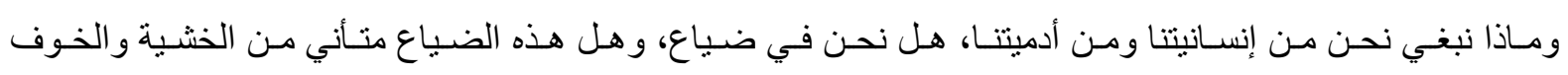

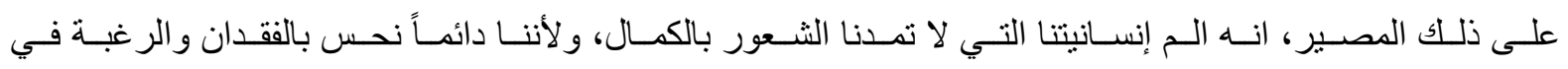
الحيازة فنظل نخشى ونخاف ونقلق.

\section{-}

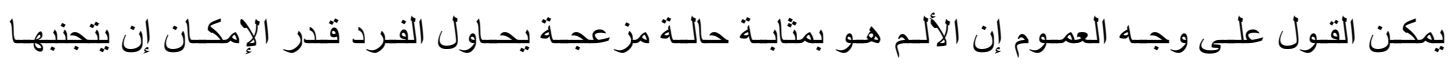

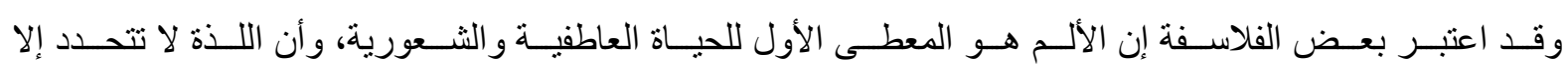
انطلاقاً منه وبالنسبة إليه و اللذة في رأي بعض المفكرين ليست سوى غياب الألم.

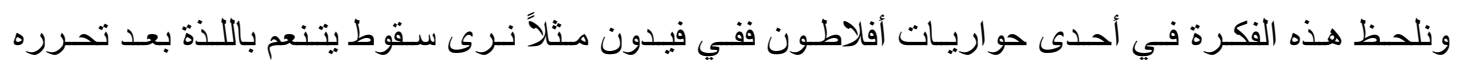

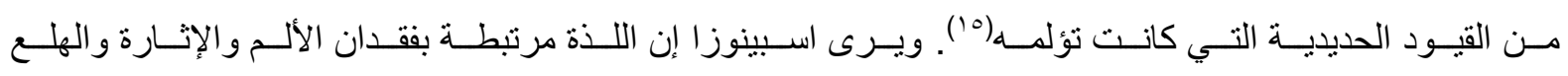

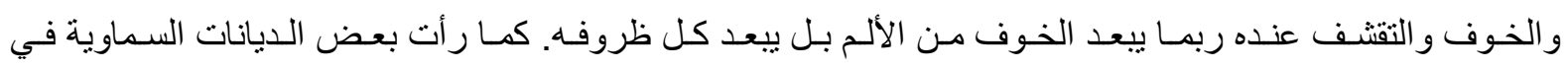


الألم ثـــة أخلاقيـة فالمسيحية تـرى على سبيل المثـال إن الألم هو فضـلة تسـمح بـالتفكير عن الخطيئة التـي ورثهـا الإنسان من ادم.

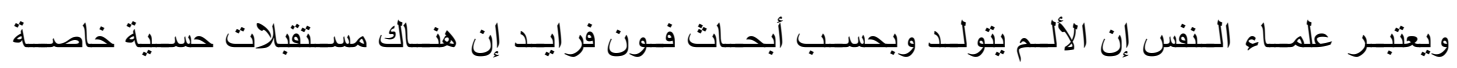

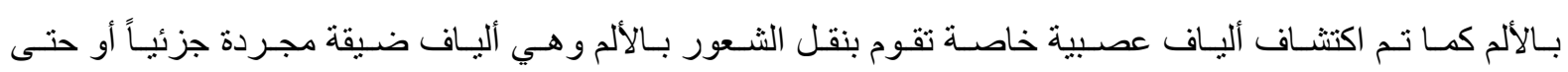

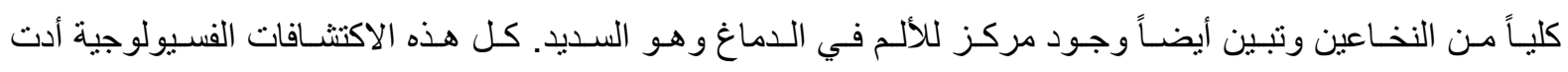

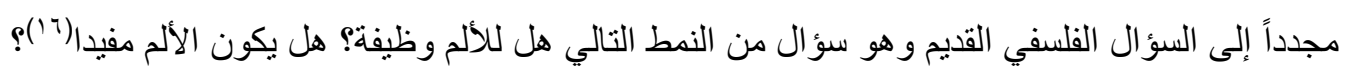

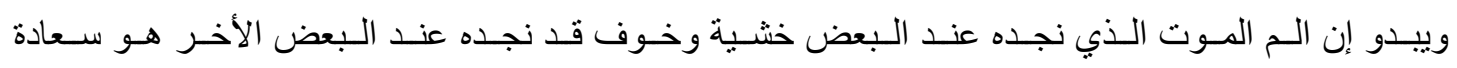

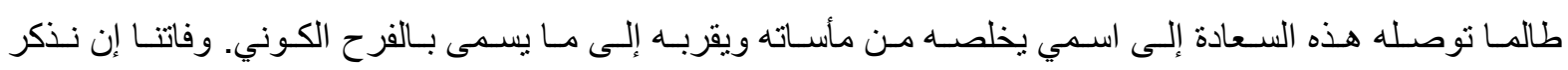

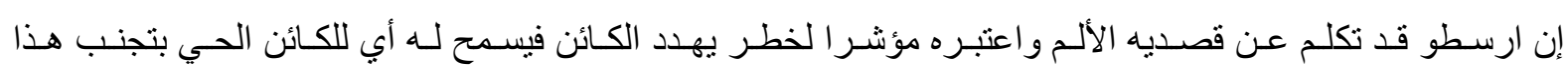

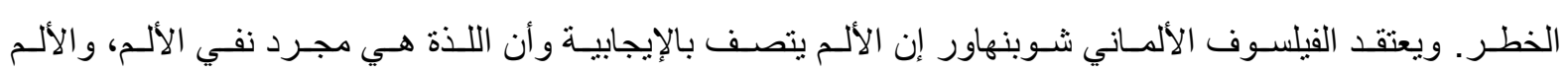

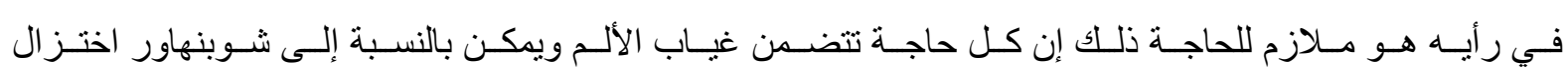
الموافقة لاختيار الموضوع إلى مجرد غياب الألم.

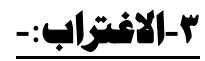

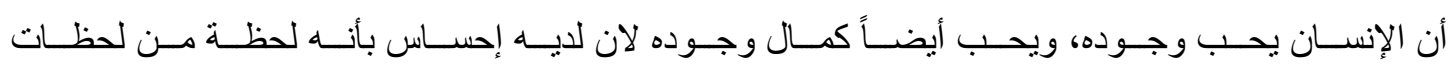

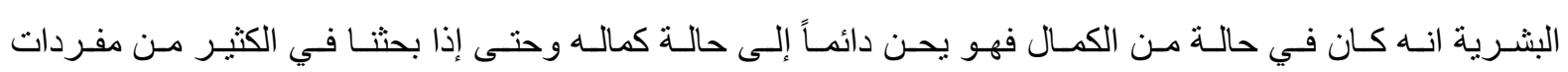

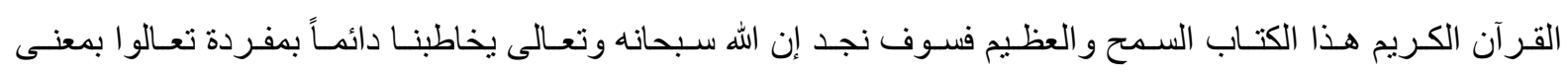
تعـالوا أدليكم على مـا هو حسن ومـا هو قبيح بمعنى اعلوا إلى مـا هو سماوي، حتى فرعون نجده قد تعـالى لكنهـ تعالى على ما هو راضي.

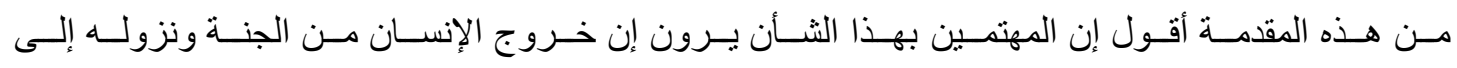

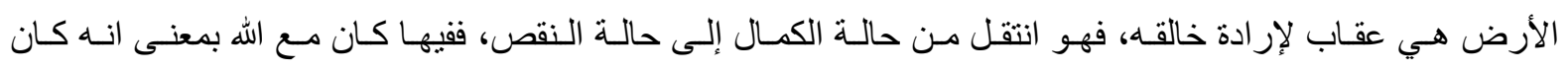

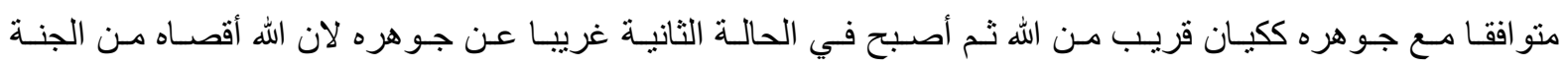
إلى الأرض ويعتبرون هذه الحالة اغتر ابا.

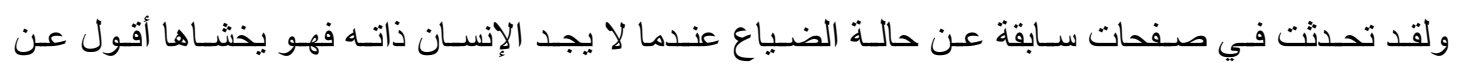
هذه الخشية هي الضياع بعينه، هي ليس من قبيل الانفعالات والمشاعر التي تنتاب الإنسان الواعي.

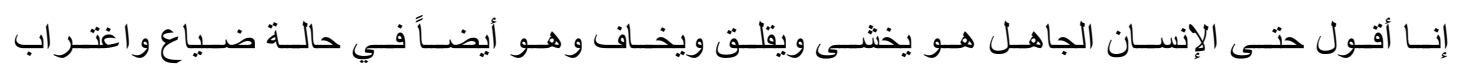

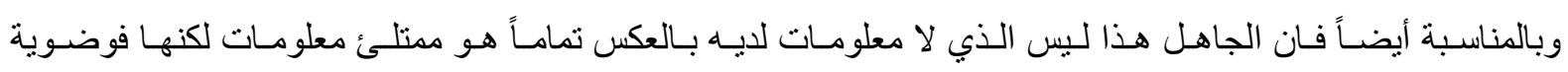
تبحث عن عنوان لها.

هيجـل يـرى إن الإنسـان يكون مغتربـا عندما لا يتعـرف على ذاتـه في هـذا العـالم ويجـاوز ذاتـه ويتجـاوز

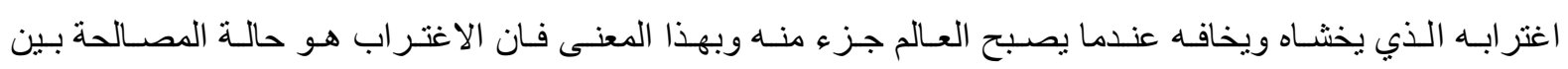
الذات و الوجود الذي يخشاه الإنسان ويقلقه.

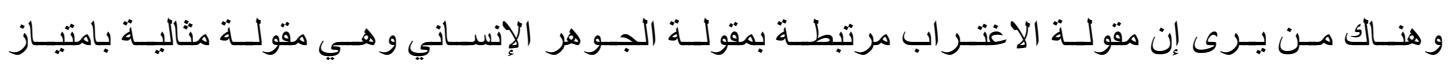

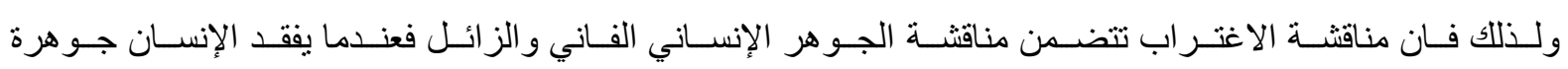




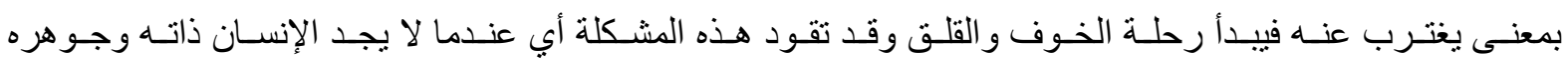

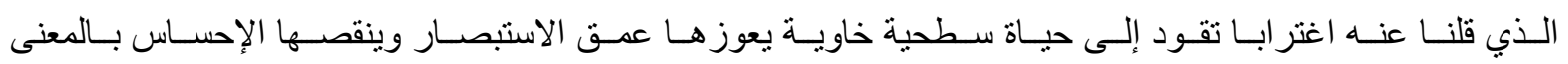

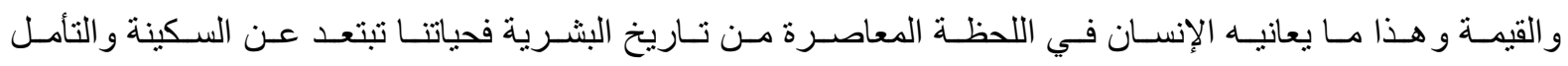

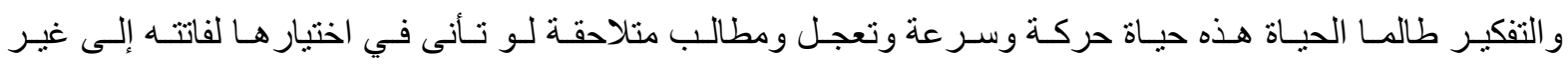

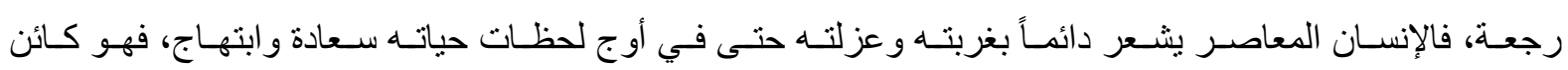
قلق وخائف من زو ال لحظات السعادة و الابتهاج هذه.

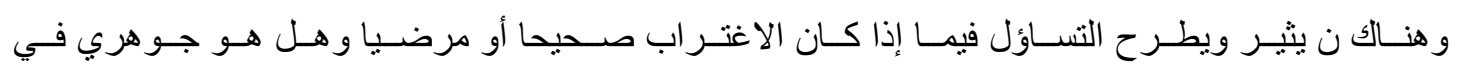

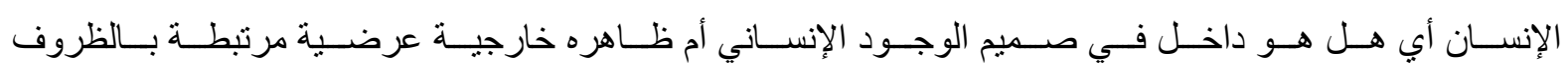

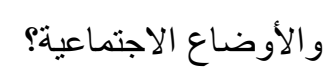
هناللك رأيان للإجابة على هذه التساؤلات

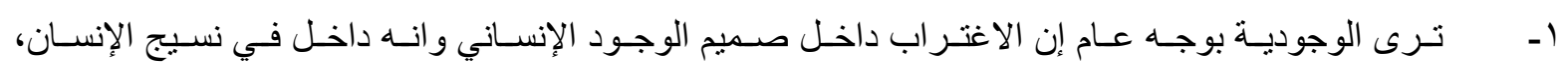

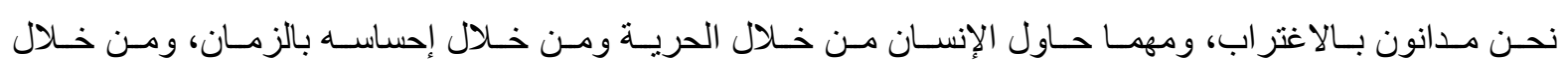

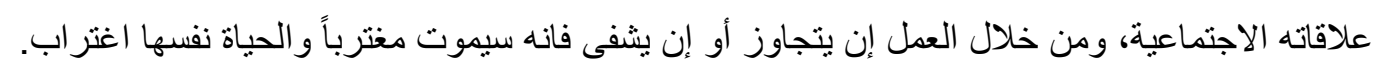

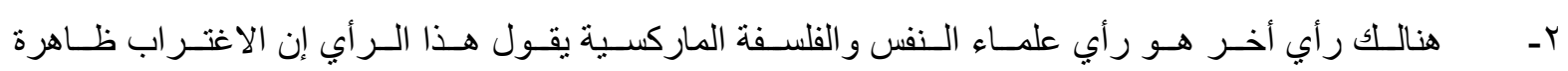

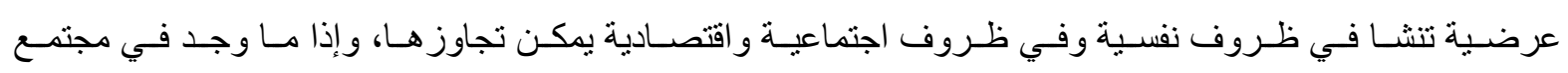

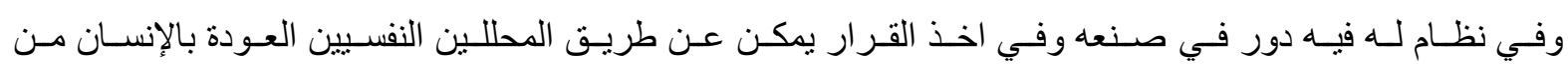
خلال تذكر ماضيه و اكتشاف ذاته وبالتالي الوصول في علاقات اجتماعية سوية مع الآخرين.

وفـي الإســلام صـحيح إن الإنســان مغتـرب، ولكنـهـ فـي نفس الوقـت سـعيد سـعادة حقيقيـة لان الإسـلام

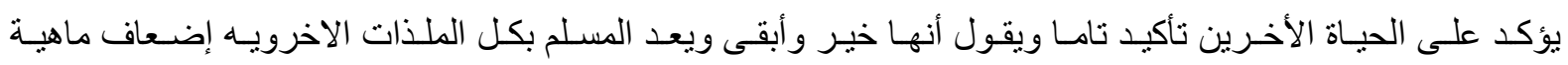

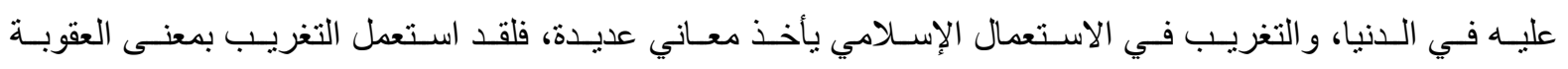

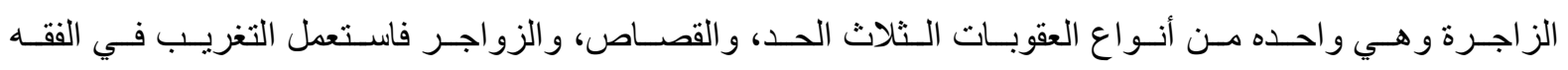

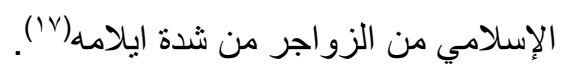

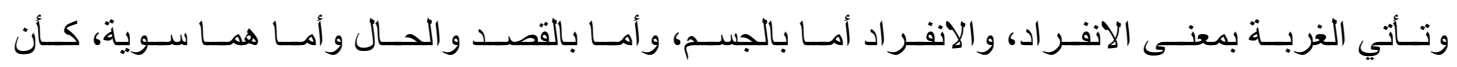

$$
\text { الغريب غريب جسم، أو غريب قلب و إرادة وحال. }
$$

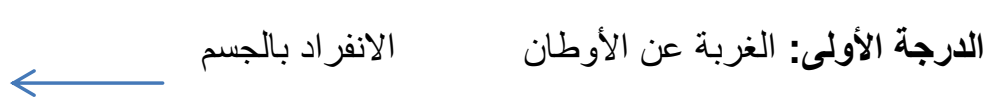

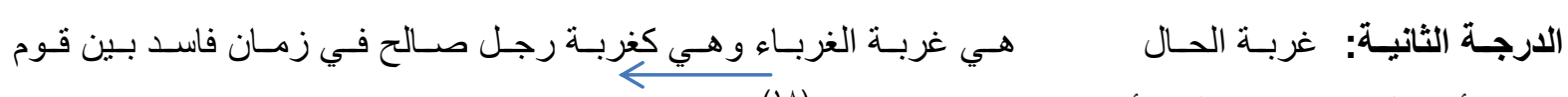

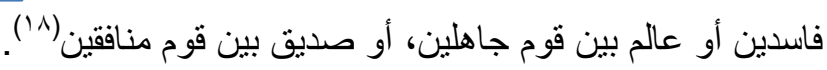

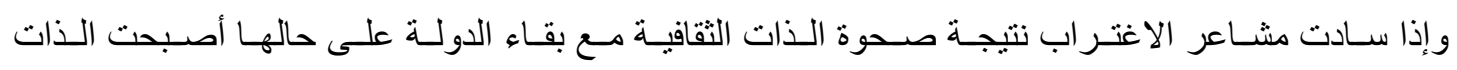

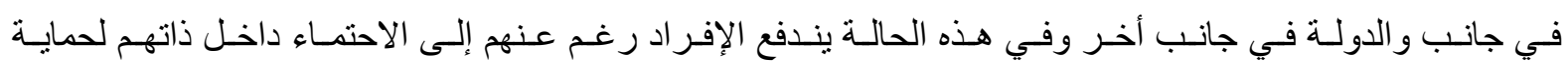

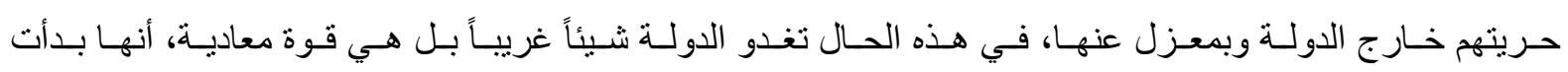

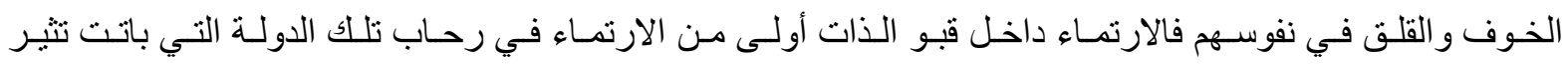




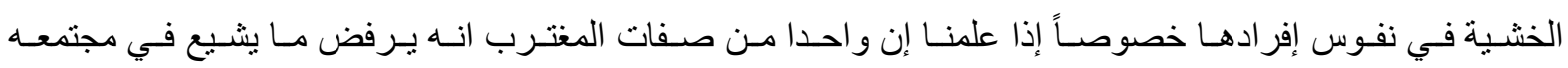
من معايير قد تكون دينية أو سياسية أو أخلاقية فاسدة أو قيم أخلاقية زائفة.

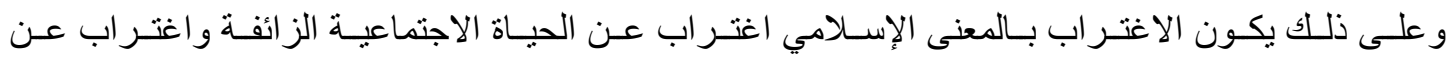

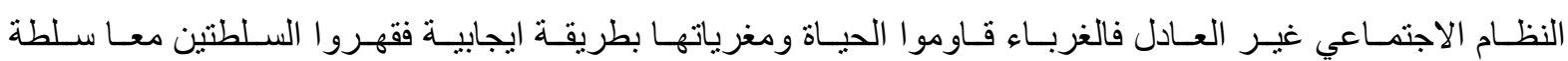

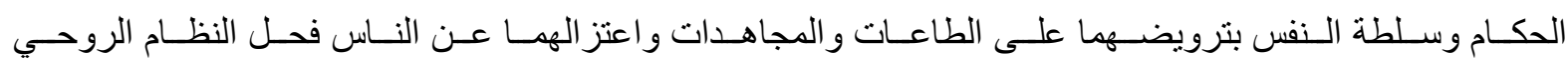

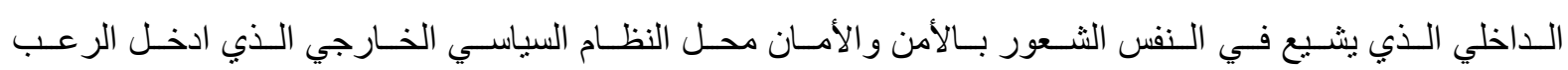
و الخوف و القلق في قلوب المسلمين بعد إن تفشت بينهم فتنة الثهو ات وفتنة الثبيهات(9 (19).

\section{العلاقة بين الفلسفة والغوف والقلق في الهضارات الثشقية القديمة:}

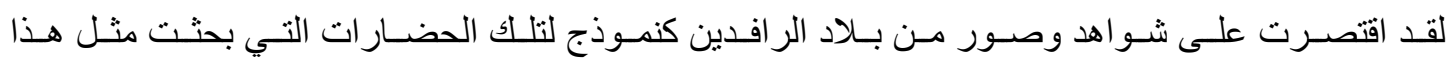

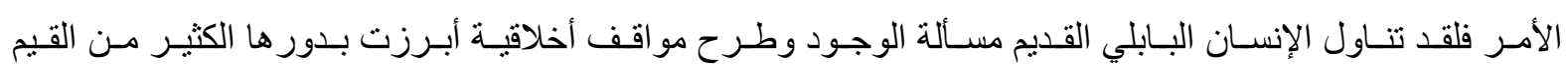

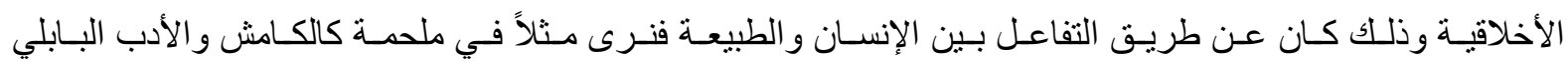

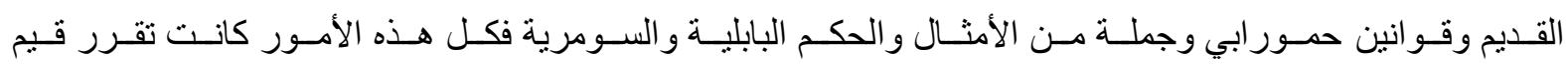

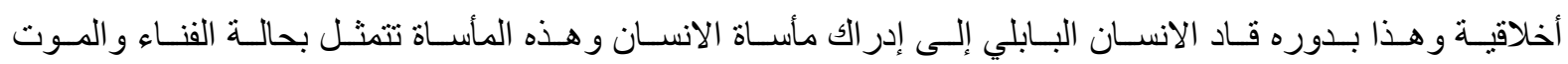

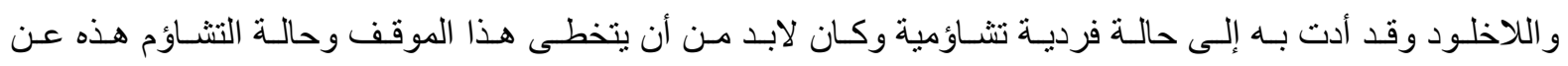

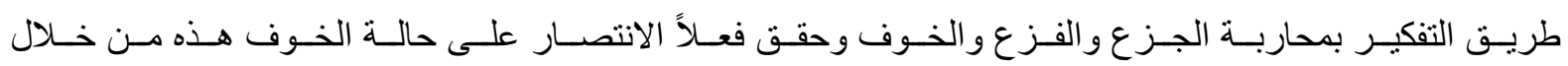

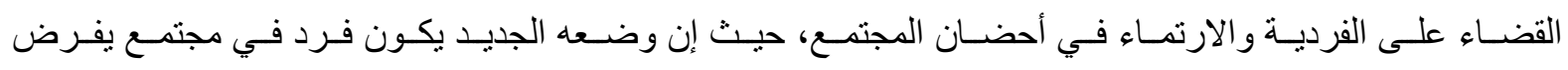

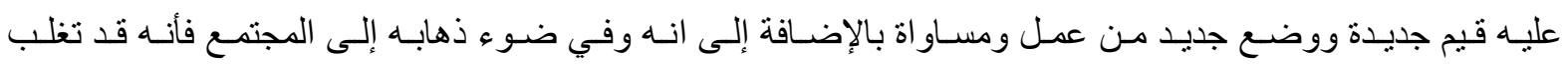

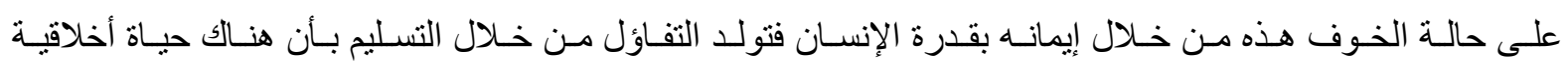
أفضل.

\section{(همرحلة النفافة بنماذه منتبمبة)}

إن الفلسفة في صـميمها تســاؤل عـن معنى الحيـاة الإنسـاني وسـعي دائب مـن اجـل تفهم حقيقـة المصـير

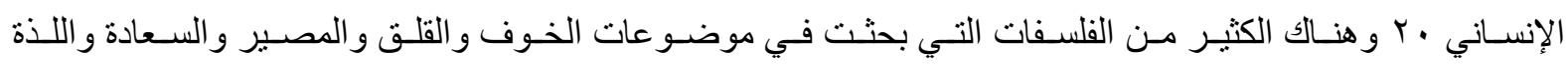

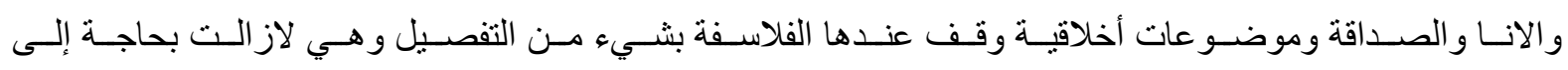

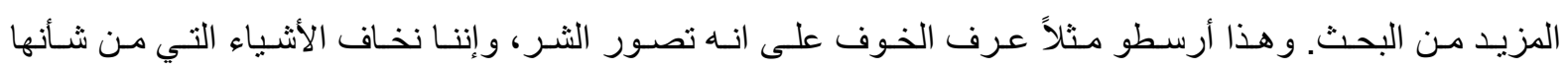

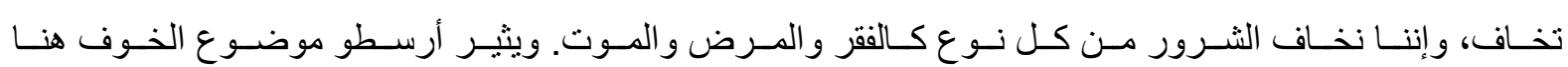

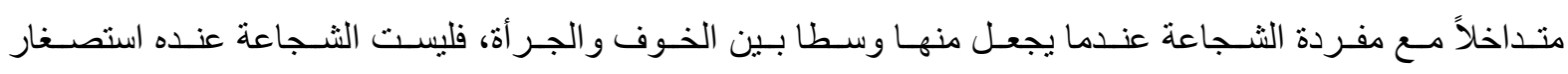

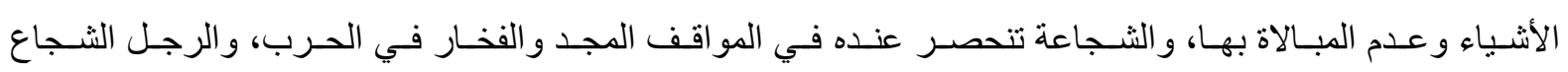

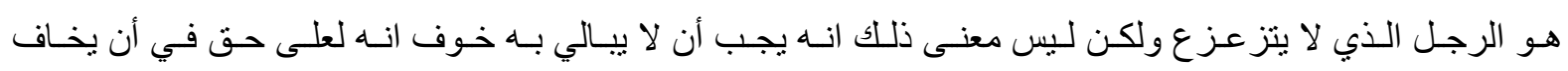

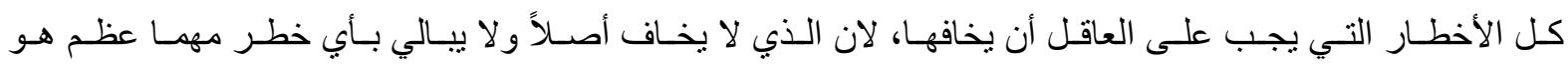
أن يسمى مشهوراً أحق منه بأن يسمى شجاع.

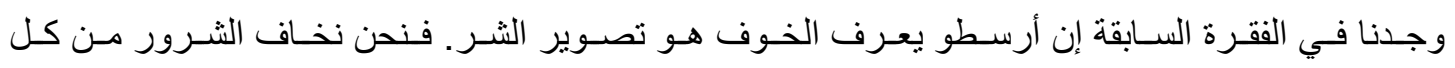

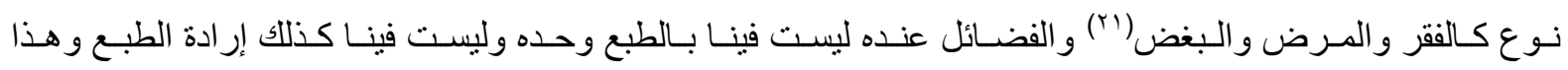


مـا دفع أرسطو للقول بـان الفضيلة مكتسبة، في هذا المقام يلتقي مـع ابن حزم في كون الفضيلة مكتسبة إذ يقول أرسطو (فرض على الناس تعلم الخير والعمل به ومن جمع الأمرين فقد استوفى الفضيلتين معا)(rr).

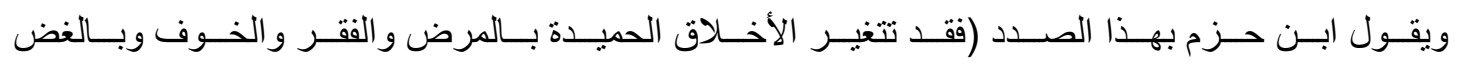

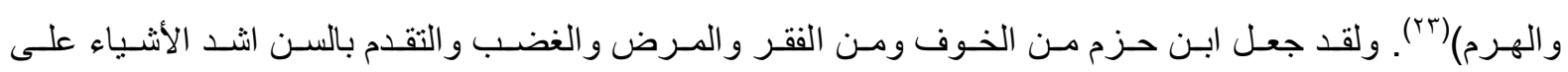

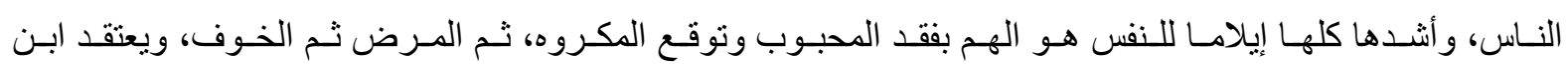

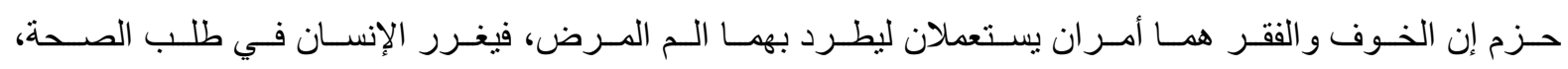

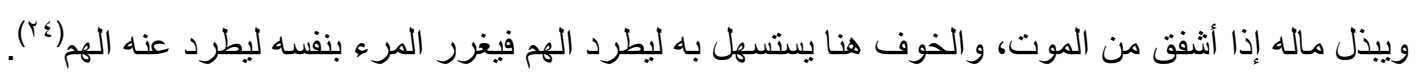

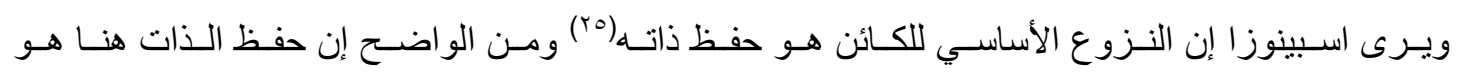

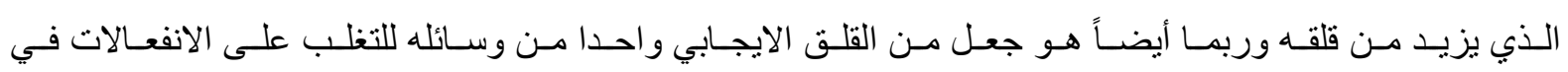
السلوك البشري والتي عدها جزء لا يتجزأ من الطبيعة البشرية وتسري عليها قو انين الطبيعة ذاتها. وقد عـرف اسـبينوزا هذه الانفعـالات بــا يتفق ومقتضـيات مذهبـه إذ يـرى إن كل فـرد يقوم أول مـا يقوم

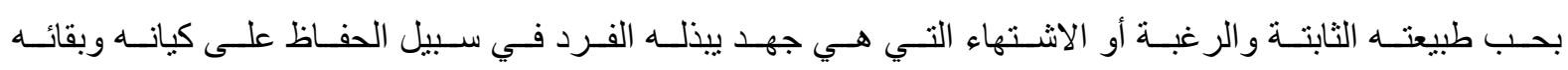

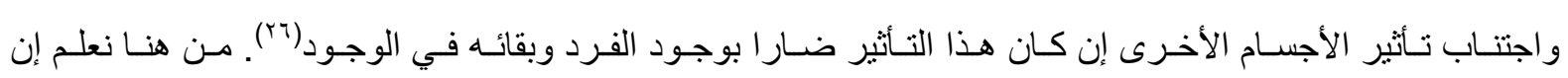

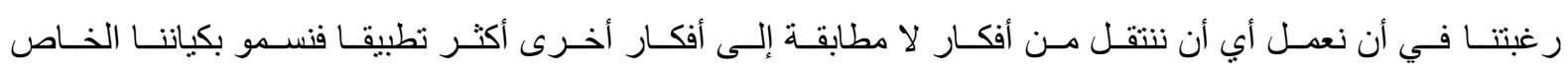

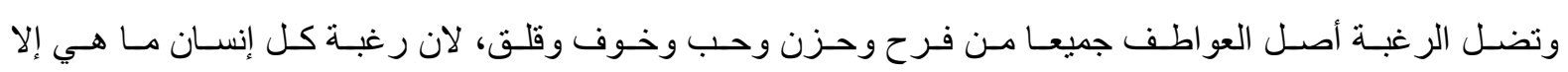
جهده لتحقيق ذاته وحفظ كيانه إلى أقصى حدا يسنطاع.

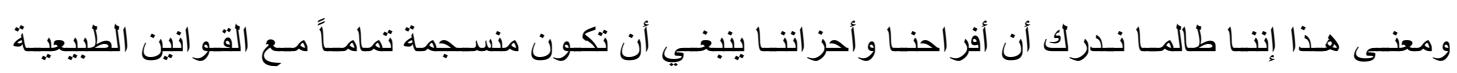

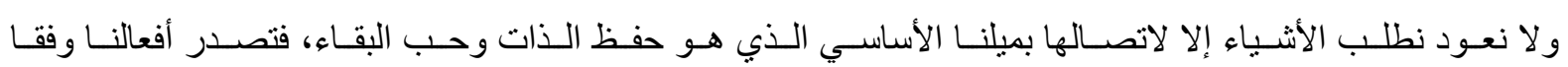

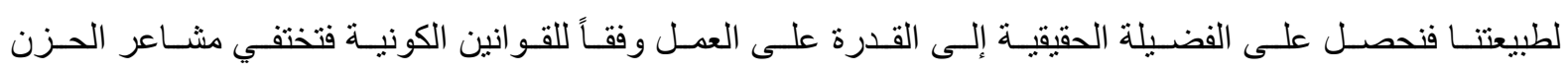

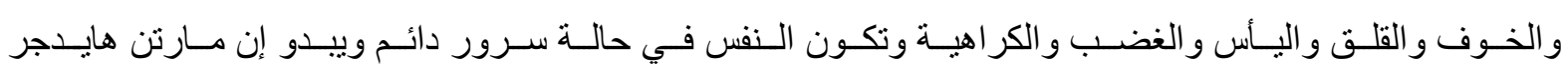

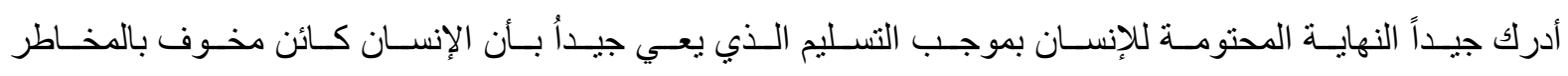

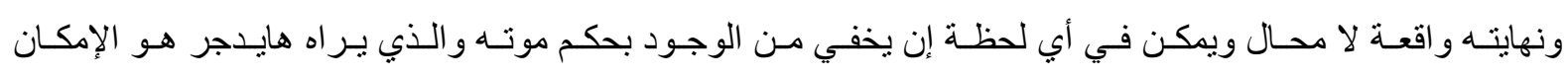

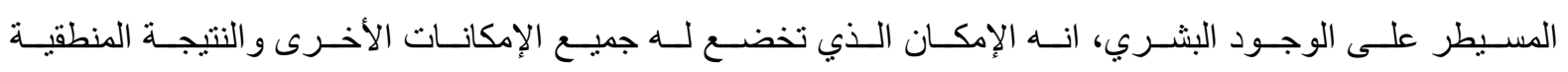
الأخرى والنتيجة المنطقية التي تترتب على ذلك هو قلق مستمر في صميم وجودنا.

\section{الإنسان الغربي والفوف هن الأزمات}

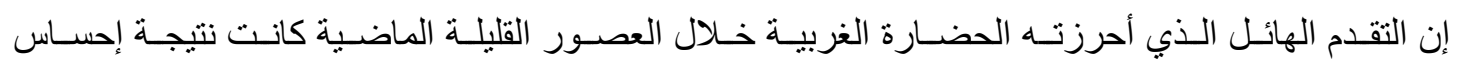

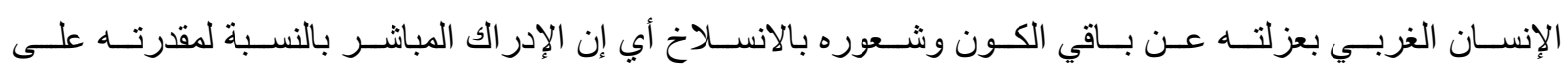

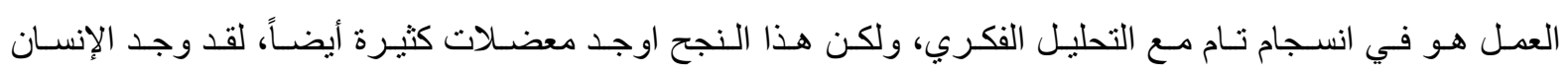

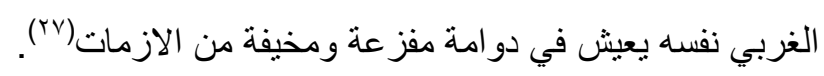

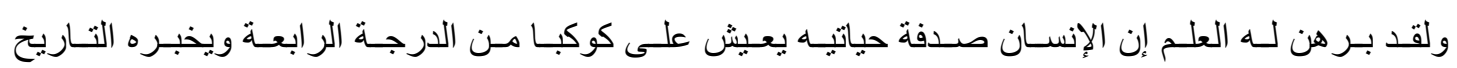

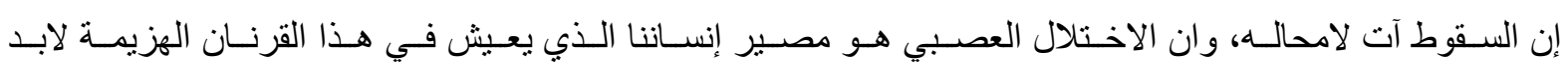

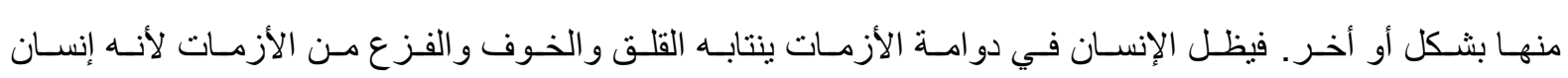

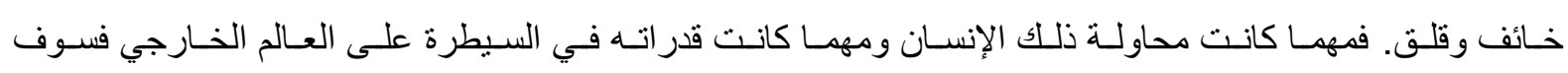




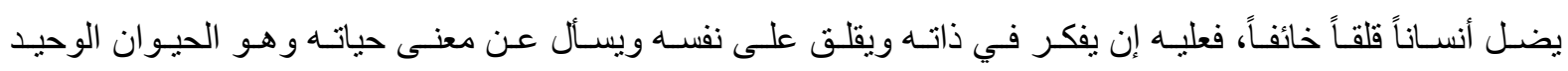
الذي يعي تماماً انه سيموت(بد).

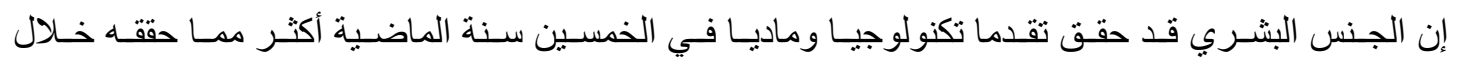

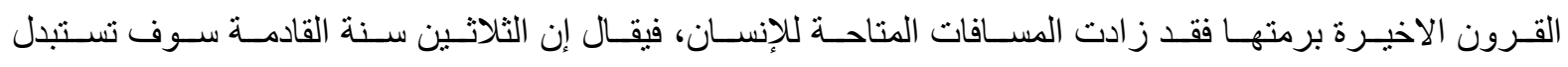

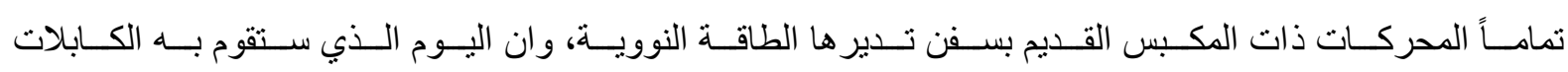

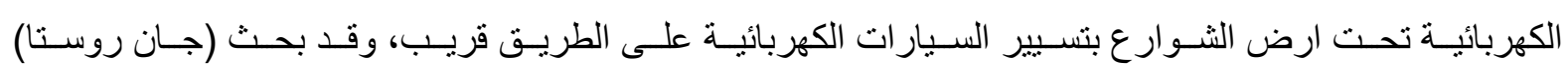

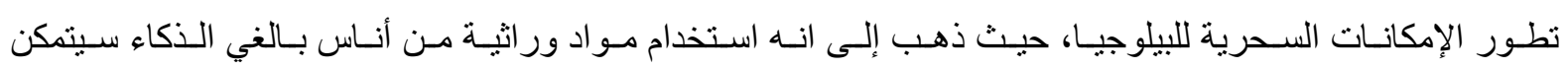

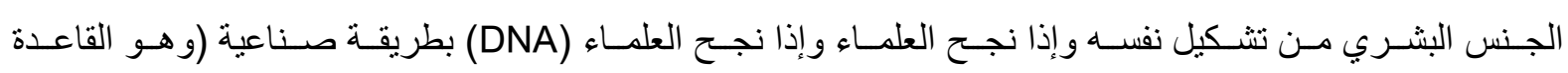

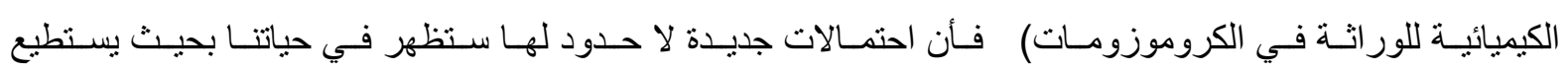

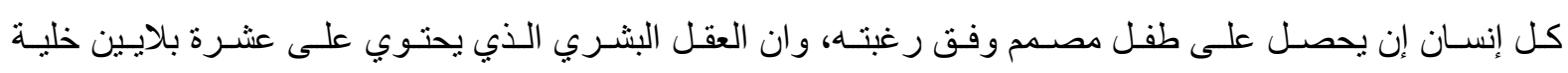

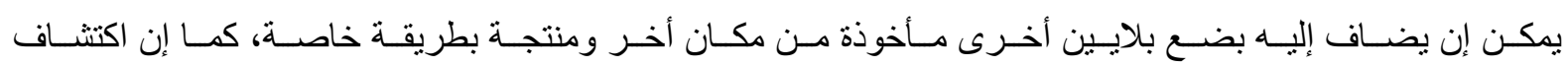

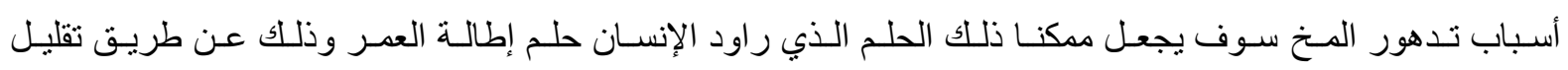
ساعات النوم الذي يحتاجها الإنسان. إن فثـل العلـم في مجـالات مختلفـة وإخفـاق الحضـارة البـين في سـعيها في حـل مشكلة الإنسـان وسـعادته

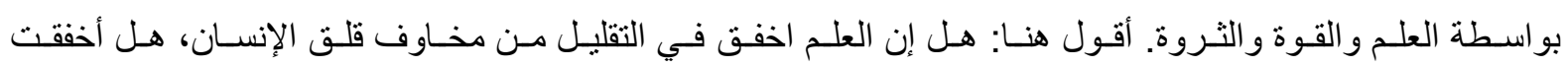

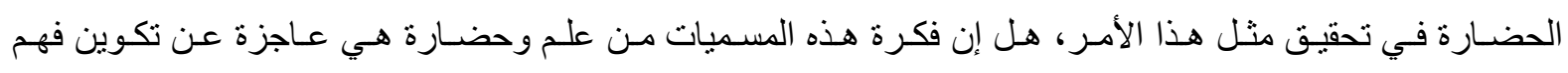

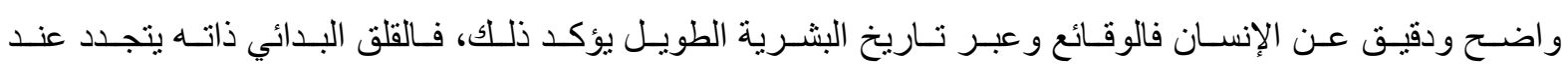

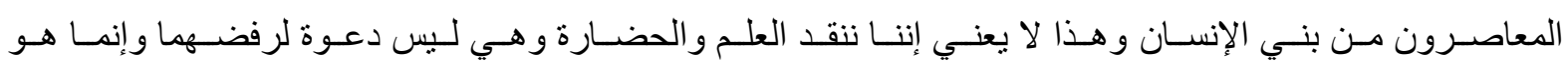

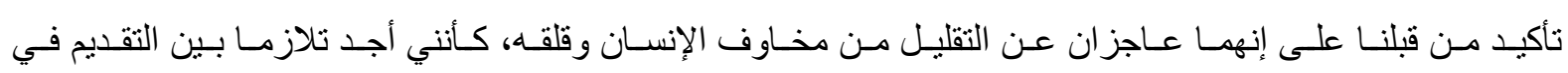

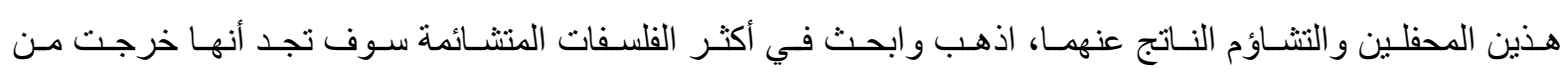
أكثر البلدان تقدما.

\section{الهواهش:}

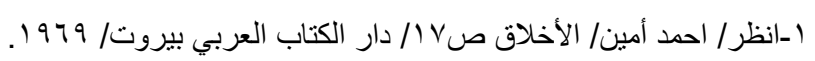

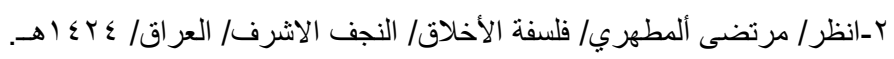

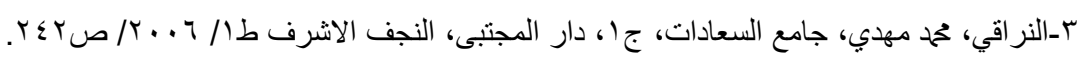

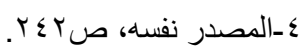

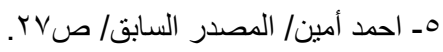

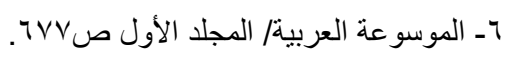

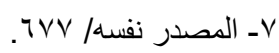

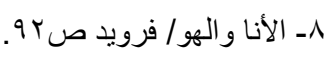
9- أبر اهيم الدر/ الأسس البيلوجية لسلوك الإنسان/ الدار العربية للعلوم ص. ـ11.

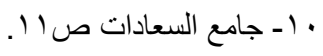

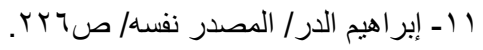

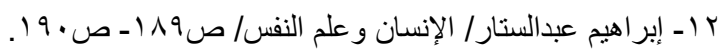

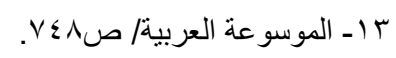

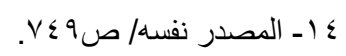


10 ـ أفلاطون/ محاورة فيدون/ ص00- ص707.

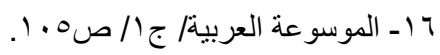

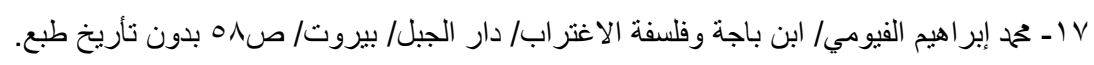

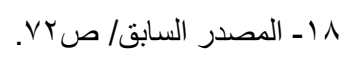

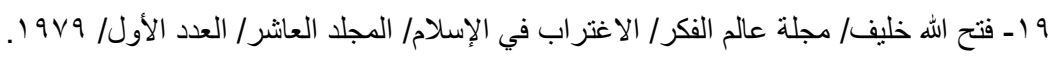

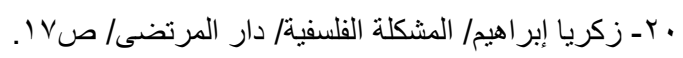

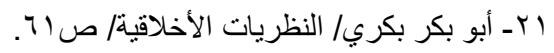

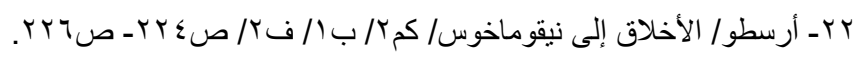

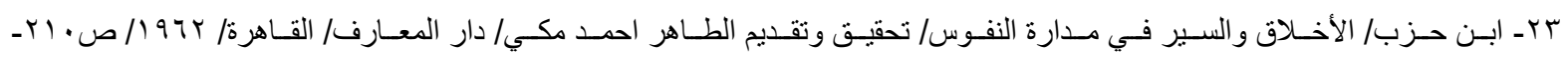

YII

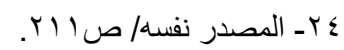

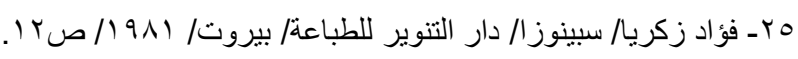

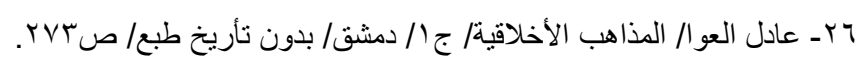

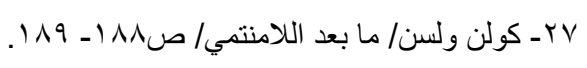

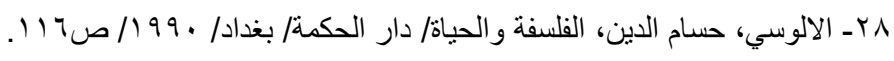

